\title{
Microalgae Tolerance to High Concentrations of Carbon Dioxide: A Review
}

\author{
Fadhil M. Salih \\ ClearValue Inc. Sugar Land, Texas, U.S.A. \\ Email: fadhil@clearvalue.com \\ Received April $2^{\text {nd }}, 2011$; revised May $6^{\text {th }}, 2011$; accepted June $3^{\text {rd }}, 2011$.
}

\begin{abstract}
The increasing concentration of carbon dioxide $\left(\mathrm{CO}_{2}\right)$ in the atmosphere is considered to be one of the main causes of the global warming problem. Moreover, there is an international movement to reduce the emission of $\mathrm{CO}_{2}$ by imposing different measures such as carbon tax. Biological $\mathrm{CO}_{2}$ fixation has been extensively investigated as part of efforts to solve the global warming problem. Microalgae are fast growing systems that can consume high quantities of $\mathrm{CO}_{2}$ to produce different types of biomass. The efficiency of microalgae is highly related to the concentration of $\mathrm{CO}_{2}$ in the growth atmosphere and the higher the concentration of $\mathrm{CO}_{2}$ the better is the growth and hence productivity. The present review aimed at shedding some light upon microalgal capability to sustain their viability and propagate under high $\mathrm{CO}_{2}$ concentration.
\end{abstract}

Keywords: Carbon Dioxide, Microalgae, Tolerance, Sequestration

\section{Introduction and Methods}

Global warming due to increased carbon dioxide concentration in the atmosphere is receiving a great deal of attention. Atmospheric increases of carbon dioxide are positively correlated with the amount of fossil fuels being burned [1]. In an effort to retard this increase and, therefore, the greenhouse effect, most industrialized countries have joined in a policy to hold carbon dioxide emissions [2]. However, it is not clear if technology exists to achieve this goal.

Generally, photosynthetic system provides critical oxygen renewal along with the recycling of carbon into potentially beneficial biomass $[3,4]$. The efficiency of such system depends on the type of the organism used $[5,6]$. Microalgae are the most promising production facilities. They are capable of fixing several-fold more $\mathrm{CO}_{2}$ per unit area than trees or crops. Such $\mathrm{CO}_{2}$ fixation by photoautotrophic algal cultures has the potential to diminish the release of $\mathrm{CO}_{2}$ into the atmosphere, helping alleviate the trend toward global warming. To realize workable biological $\mathrm{CO}_{2}$ fixation systems, selection of optimal microalgae species is vital. The selection of optimal microalgae species depends on specific strategies employed for $\mathrm{CO}_{2}$ sequestration.

Viewing microalgae farms or bioreactors as means to reduce the effects of a greenhouse gas $\left(\mathrm{CO}_{2}\right)$ changes the view of the economics of the process. Instead of requiring that microalgae-derived fuel be cost competitive with fossil fuels, the process economics must be compared with those of other technologies proposed to deal with the problem of $\mathrm{CO}_{2}$ pollution. However, development of alternative, environmentally safer energy production technologies will benefit society whether or not global climate change actually occurs [7]. Microalgal biomass production has great potential to contribute to world energy supplies, and to control $\mathrm{CO}_{2}$ emissions as the demand for energy increases. This technology makes productive use of arid and semi-arid lands and highly saline water, resources that are not suitable for agriculture and other biomass technologies [8].

Although $\mathrm{CO}_{2}$ is still released when fuels derived from algal biomass are burned, integration of microalgal farms for flue gas capture approximately doubles the amount of energy produced per unit of $\mathrm{CO}_{2}$ released. Materials derived from microalgal biomass also can be used for other long-term uses, serving to sequester $\mathrm{CO}_{2}$. Flue gas has the potential to provide sufficient quantities of $\mathrm{CO}_{2}$ for such large-scale microalgae farms [9].

\section{2. $\mathrm{CO}_{2}$ Tolerant Microalgae}

Electrical power plants are responsible for over one-third of the U.S. emissions or about $2.2 \times 10^{9}$ tonns $\mathrm{CO}_{2}$ per 
year [10]. Direct utilization of power plant flue gas has been considered for $\mathrm{CO}_{2}$ sequestration systems [11]. The advantage of utilizing flue gas directly is the reduction of the cost of separating $\mathrm{CO}_{2}$ gas. Since power plant flue gas contains a higher concentration of $\mathrm{CO}_{2}[12,13]$ identifying high $\mathrm{CO}_{2}$ tolerant species is important. Although $\mathrm{CO}_{2}$ concentrations vary depending on the flue gas source [10], $15 \%-20 \% \mathrm{v} / \mathrm{v}$ is typically assumed. Several species have been tested under $\mathrm{CO}_{2}$ concentrations of over 15\%, as given in Table 1 [5].

One of the high $\mathrm{CO}_{2}$ tolerant species is Euglena gracilis. Growth of this species was enhanced under $5 \%-45 \%$ concentration of $\mathrm{CO}_{2}$. The best growth was observed with $5 \% \mathrm{CO}_{2}$ concentration. However, the species did not grow under greater than $45 \% \mathrm{CO}_{2}$ [18]. Hirata et al., $[23,24]$ reported that Chlorella sp. UK001 could grow successfully under $10 \% \mathrm{CO}_{2}$ conditions. It is also reported that Chlorella sp. can be grown under $40 \% \mathrm{CO}_{2}$ conditions [15]. Furthermore, Maeda et al., [25] found a strain of Chlorella sp. T-1 which could grow under $100 \%$ $\mathrm{CO}_{2}$, although the maximum growth rate occurred under a $10 \%$ concentration, while Scenedesmus sp. could grow under $80 \% \mathrm{CO}_{2}$ conditions but the maximum cell mass was observed in $10 \%-20 \% \mathrm{CO}_{2}$ concentrations [15]. Cyanidium caldarium [14] and some other species of Cyanidium can grow in pure $\mathrm{CO}_{2}$ [26].

Generally, phototrophic microalgal growth requires a supply of carbon dioxide as a carbon source. $\mathrm{CO}_{2}$ supply contributes to control the $\mathrm{pH}$ of the culture [27]. Chemical analysis has shown that algal biomass consists of $40 \%$ to $50 \%$ carbon, which suggests that about 1.5 to 2.0 $\mathrm{kg}$ of $\mathrm{CO}_{2}$ is required to produce $1.0 \mathrm{~kg}$ of biomass [28]. According to previous studies, the supply of carbon to microalgal mass culture systems is one of the principal difficulties and limitations that must be solved $[11,29,30]$. The principal point of all considerations relating to the $\mathrm{CO}_{2}$ budget is that, on the one hand, $\mathrm{CO}_{2}$ must not reach

Table 1. $\mathrm{CO}_{2}$ tolerance of various species [5].

\begin{tabular}{ccc}
\hline Species & $\begin{array}{c}\text { Known } \\
\text { Maximum } \mathrm{CO}_{2}\end{array}$ & $\begin{array}{c}\text { Concentration } \\
\text { References }\end{array}$ \\
\hline Cyanidium caldarium & $100 \%$ & {$[14]$} \\
Scenedesmus sp. & $80 \%$ & {$[15]$} \\
Chlorococcum littorale & $60 \%$ & {$[16]$} \\
Synechococcus elongatus & $60 \%$ & {$[17]$} \\
Euglena gracilis & $45 \%$ & {$[18]$} \\
Chlorella sp. & $40 \%$ & {$[19]$} \\
Eudorina spp. & $20 \%$ & {$[20]$} \\
Dunaliella tertiolecta & $15 \%$ & {$[21]$} \\
Nannochloris sp. & $15 \%$ & {$[22]$} \\
Chlamydomonas sp. & $15 \%$ & {$[23]$} \\
Tetraselmis sp. & $14 \%$ & {$[24]$} \\
\hline
\end{tabular}

the upper concentration that produces inhibition and, on the other hand, must never fall below the minimum concentration that limits growth [31]. These maximum (inhibition) and minimum (limitation) concentrations vary from one species to another and are not yet adequately known, ranging from $2.3 \times 10^{-2} \mathrm{M}$ to $2.3 \times 10^{-4} \mathrm{M}[31$, 32].

\section{Sustainability of Photosynthetic Organisms}

The previously held notion that unlike terrestrial plants, submerged plants like algae will not show any response to an increase of atmospheric carbon dioxide. This view may be biased by a neglect of the effects of the plants themselves on the water chemistry [33]. If this effect is included, productivity may double due to a doubling of the atmospheric carbon dioxide concentration. In practice productivity increase will usually be less, however, under nutrient rich conditions, doubling of atmospheric carbon dioxide may result in a productivity increase up to $40 \%$ in saltwater species and up to $50 \%$ in freshwater species [34]. These results indicate that the carbon uptake by fresh and saltwater systems may increase more than expected, and that nuisance algal blooms may be aggravated at elevated atmospheric carbon dioxide concentrations.

Moreover, plants grown in elevated atmospheric $\mathrm{CO}_{2}$ environments typically exhibit increased rates of photosynthesis and biomass production [35]. Most of the studies that have established this fact have historically utilized $\mathrm{CO}_{2}$ concentration increases on the order of 300 $400 \mathrm{ppm}$, which represents an approximate doubling of the air's current $\mathrm{CO}_{2}$ concentration; and they have been conducted on terrestrial plants $[36,37]$.

Andersen et al. [38] grew specimens of Littorella uniflora, one of the isoetids (small slow-growing evergreen perennials that live submerged along the shores of numerous freshwater lakes and rely primarily on sediment-derived $\mathrm{CO}_{2}$ for their photosynthesis) in sediment cores removed from Lake Hampen (Denmark) in 75-liter tanks. The end result of these experiments was that the ultra- $\mathrm{CO}_{2}$-enriched water led to an approximate $30 \%$ increase in plant biomass. In a different study Anderson and Anderson [39] measured the $\mathrm{CO}_{2}$-induced in situ growth response of a mixture of several species of filamentous freshwater algae (dominated by Zygnema species, but containing some Mougeotia and Spirogyra), as well as an isoetid community of macrophytes (dominated by Littorella uniflora, but containing some Myriophyllum alterniflorum and a few other species). After one full growing season (May to November), they determined that the ten-fold increase in aquatic $\mathrm{CO}_{2}$ enhanced the biomass production of Littorella uniflora by approximately $78 \%$. Simultaneously, the biomass of filamentous algae was also enhanced by 
the elevated $\mathrm{CO}_{2}$ : by $220 \%$ in early July, by $90 \%$ in midAugust, and by a whopping 3,750\% in mid-November.

A red seaweed common to the Northeast Atlantic intertidal zone, Lomentaria articulata, was grown for three weeks in hydroponic cultures subjected to various atmospheric $\mathrm{CO}_{2}$ and $\mathrm{O}_{2}$ concentrations to determine the effects of these gases on growth [40]. In doing so, they found that oxygen concentrations ranging from 10 to $200 \%$ of ambient had no significant effects on daily net carbon gain or total wet biomass production rates in this particular seaweed. In contrast, $\mathrm{CO}_{2}$ concentrations ranging from 67 to $500 \%$ of ambient had highly significant effects on these parameters. At twice the current ambient $\mathrm{CO}_{2}$ concentration, for example, daily net carbon gain and total wet biomass production rates were 52 and $314 \%$ greater than they were under ambient $\mathrm{CO}_{2}$ conditions. Likewise, Tisserat [41] grew water mint (Mentha aquatica) plants for four weeks at ambient and enriched atmospheric $\mathrm{CO}_{2}$ conditions, finding that compared to plants exposed to air of $350 \mathrm{ppm} \mathrm{CO}$, those grown in air of $3,000 \mathrm{ppm} \mathrm{CO} \mathrm{CO}_{2}$ produced $220 \%$ more fresh weight.

Microalgae response to varying $\mathrm{CO}_{2}$ concentrations has been widely investigated. Chlorella vulgaris was cultivated under various light intensities in a gas recycling photobioreactor. The light intensity affected the algal growth and the $\mathrm{CO}_{2}$ concentration in the exit gas. In the linear growth phase, $\mathrm{CO}_{2}$ concentration in the exit gas ranged between $4.6 \%$ to $6.0 \%(\mathrm{v} / \mathrm{v})$ when $20 \%(\mathrm{v} / \mathrm{v})$ $\mathrm{CO}_{2}$ balanced with $80 \%(\mathrm{v} / \mathrm{v}) \mathrm{N}_{2}$ was introduced into the photobioreactor [42].

In search of a simple method for removing $\mathrm{CO}_{2}$ from high- $\mathrm{CO}_{2}$-concentration stack gases, Yue and Chen [43] isolated and cultured a freshwater microalga of the genus Chlorella for periods of six days in vessels filled with growth media through which air of a variety of different $\mathrm{CO}_{2}$ concentrations was continuously bubbled. Data revealed that algal growth rates some $200 \%$ greater than those observed in ambient air were common at 100,000 ppm $\mathrm{CO}_{2}$. Thereafter, however, at higher $\mathrm{CO}_{2}$ concentrations, algal growth rates began to slowly decline; but they continued to remain greater than the growth rate observed in ambient air. Relative to that baseline, for example, the algal growth rate at $200,000 \mathrm{ppm} \mathrm{CO}_{2}$ was $170 \%$ greater, that at $300,000 \mathrm{ppm}$ was $125 \%$ greater, and that at $500,000 \mathrm{ppm}$ was about $40 \%$ greater. Similar results were obtained by Watanabe et al. [44] for another Chlorella alga, by Hanagata et al. [15] for both Chlorella and Scenedesmus species, and by Kodama et al. [16] for the marine microalga Chlorococcum littorate.

Euglena cells were cultured to determine the maximum $\mathrm{CO}_{2}$ elimination rate under a high concentration of $\mathrm{CO}_{2}$ with stirring of the supplied gas by bubbling. It was found that the maximum $\mathrm{CO}_{2}$ elimination rate or gas ex- change performance under a $10 \%$ concentration of $\mathrm{CO}_{2}$ was 2.3 times higher than $0.03 \%$ of $\mathrm{CO}_{2}$ concentration. The results suggest that the $\mathrm{CO}_{2}$ concentration in the supplied gas rate limits the algal system performance [45].

The effect of increased $\mathrm{CO}_{2}$ concentration on the growth rate of three planktonic algae (Chlamydomonas reinhardtii, Chlorella pyrenoidosa, and Scenedesmus obliquus) enhanced significantly [46]. Specific growth rates reached maximal values at 30,100 , and $60 \mu \mathrm{M} \mathrm{CO}_{2}$ in C. reinhardtii, C. pyrenoidosa, and S. obliquus, respectively. Such significant enhancement of growth rate with enriched $\mathrm{CO}_{2}$ was also confirmed at different levels of inorganic $\mathrm{N}$ and $\mathrm{P}$. The maximal rates of net photosynthesis, photosynthetic efficiency and light-saturating point increased significantly in high- $\mathrm{CO}_{2}$-grown cells. The authors concluded that increased $\mathrm{CO}_{2}$ concentrations with decreased $\mathrm{pH}$ could affect the growth rate and photosynthetic physiology of the three algae species.

In a different study [15] Chlorella species showed much higher log phase growth rates, while Scenedesmus species was better able to tolerate very high $\mathrm{CO}_{2}$ concentrations than Chlorella. However, both algae had about the same growth rate when the $\mathrm{CO}_{2}$ concentration was in the range $10 \%-30 \%$. Scenedesmus was completely inhibited by $100 \% \mathrm{CO}_{2}$. This inhibition was reversible since growth was resumed when $\mathrm{CO}_{2}$ concentration was returned to $20 \%$. Other microalgae species, Chlorella minutissima, grown under extreme carbon dioxide concentrations $(0.036 \%-100 \%)$, strongly increase the microalgal biomass through photochemical and non-photochemi- cal changes in the photosynthetic apparatus [47]. In conclusion, these extreme $\mathrm{CO}_{2}$ concentrations - about 1,000 times higher than the ambient one - can be easily metabolized from the unicellular green alga to biomass and can be used, on a local scale at least, for the future development of microalgal photobioreactors for the mitigation of the point source-produced carbon dioxide. Similar conclusion was derived by Prof. Shiraiwa's Laboratory [48] that some microalgae could grow very rapidly at a $\mathrm{CO}_{2}$ concentration higher than $40 \%$, those cells being referred to as extremely high- $\mathrm{CO}_{2}$ cells.

Yun, et al., [42] cultivated Chlorella vulgaris in wastewater discharged from a steel-making plant with the aim of developing an economically feasible system to remove ammonia from wastewater and $\mathrm{CO}_{2}$ from flue gas simultaneously (since no phosphorus compounds existed in wastewater, external phosphate $\left(15.3-46.0 \mathrm{~g} \cdot \mathrm{m}^{-3}\right)$ was added to the wastewater). After adaptation to $5 \%(\mathrm{v} / \mathrm{v})$ $\mathrm{CO}_{2}$, the growth of $C$. vulgaris was significantly improved at a typical concentration of $\mathrm{CO}_{2}$ in flue gas of $15 \%(\mathrm{v} / \mathrm{v})$. Growth of $C$. vulgaris in raw wastewater was 
better than that in wastewater buffered with HEPES at $15 \%(\mathrm{v} / \mathrm{v}) \mathrm{CO}_{2} . \mathrm{CO}_{2}$ fixation and ammonia removal rates were estimated as $260 \mathrm{~g} \mathrm{CO}_{2} \mathrm{~m}^{-3} \cdot \mathrm{h}^{-1}$ and $0.92 \mathrm{~g} \mathrm{NH}_{3}$ $\mathrm{m}^{-3} \cdot \mathrm{h}^{-1}$, respectively, when the alga was cultivated in wastewater supplemented with $460 \mathrm{~g} \mathrm{PO}_{4}^{-3} \cdot \mathrm{m}^{-3}$ without $\mathrm{pH}$ control at $15 \%(\mathrm{v} / \mathrm{v}) \mathrm{CO}_{2}$.

\section{Mechanisms of $\mathrm{CO}_{2}$ Tolerance}

The mechanistic implications of the effect of the elevated $\mathrm{CO}_{2}$ concentration on algal growth and productivity was previously studied $[15,47,49]$. The cells of Dunaliella tertiolecta grown under ordinary air (low- $\mathrm{CO}_{2}$ cells) had a well developed pyrenoid with many more starch granules than those grown under air enriched with $\mathrm{CO}_{2}$ (high- $\mathrm{CO}_{2}$ cells). The chloroplast was located close to the plasma membrane in low- $\mathrm{CO}_{2}$ cells, while that in high$\mathrm{CO}_{2}$ cells was located in the inner area of the cells. Chloroplast envelope was electronically denser in low$\mathrm{CO}_{2}$ cells than in high- $\mathrm{CO}_{2}$ cells, while the opposite effect of $\mathrm{CO}_{2}$ was observed for the plasma membrane [50]. This implies that microalgae can possibly tolerate high concentration of $\mathrm{CO}_{2}$ by adjusting their structural anatomy and redistribution of certain cellular organelles [47].

\section{Factors Influencing $\mathrm{CO}_{2}$ Tolerance}

The presence of oxygen plays a role in controlling the efficiency of $\mathrm{CO}_{2}$ uptake. Becker [51] calculated that a concentration of $\mathrm{CO}_{2}$, as low as $10^{-6} \mathrm{~mol} / \mathrm{l}(30 \mathrm{ppm})$ is sufficient to maintain unlimited photosynthesis of the algae. On the other hand, experiments with different $\mathrm{O}_{2}$ concentrations in the medium have shown the photosynthetic efficiency is increased by $14 \%$ if almost no $\mathrm{O}_{2}$ is present in the medium but is reduced to about $35 \%$ when the medium is saturated with $100 \% \mathrm{O}_{2}$. However, another study showed that oxygen concentrations ranging from 10 to $200 \%$ of ambient had no significant effects on daily net carbon gain or total wet biomass production rates in this particular seaweed [40].

Generally speaking, the effects of various combinations of $\mathrm{CO}_{2}$ concentration, light intensity and oxygen concentration on photosynthesis and growth in several algal types suggest the following.

- Different algae show different responses to high oxygen concentrations and high light intensities. Generally, inhibition of photosynthesis $\left(\mathrm{CO}_{2}\right.$ fixation and growth), increases with increasing oxygen concentration and with increasing light intensity (at light intensities greater than saturation) [51-55]. This is very much in favor of using these biological systems for the production of biofuel in various climates.

- The environmental conditions play a determining role in promoting $\mathrm{CO}_{2}$ fixation and cellular propagation. For example, a hot spring alga (HSA) purified from an alkaline hot spring ( $\mathrm{pH} 9.3$ and $62^{\circ} \mathrm{C}$ ) in Taiwan grows well over $\mathrm{pH} 11.5$ and $50^{\circ} \mathrm{C}$. For performance of $\mathrm{HSA}, \mathrm{CO}_{2}$ removal efficiencies in the packed tower increase about 5-fold in a suitable growth condition compared to that without adding alkaline salt such as potassium hydroxide. In addition, HSA also exhibits a high growth rate under the controlled $\mathrm{pHs}$ from 7 to 11 [56].

- Basic growth nutrients must be available in order to maintain proper physiological integration of the culture. This can reasonably be overcome using wastewater [57-59].

- Temperature can be a determining factor in the selection of the algal species $[60,61]$. However, the diversity in the optimum temperature required to maintain the best growth rates makes it possible to choose the organism with given physical needs [62].

\section{Conclusions}

In considering the results of the studies described above, it would appear that super-elevated atmospheric $\mathrm{CO}_{2}$ concentrations are not detrimental to freshwater and marine microalgae and macrophytes. In fact, they suggest that huge increases in aquatic $\mathrm{CO}_{2}$ concentration can sometimes lead to equally huge increases in aquatic plant growth. For the purpose of $\mathrm{CO}_{2}$ sequestration, the use of microalgae is a unique technology. In fact microalgae sit on the top of the choices for its exceptionally high efficiency in energy conversion, $\mathrm{CO}_{2}$ removal and the size and usefulness of other byproducts. The technology, which is an environmentally friendly, works under limited $\mathrm{O}_{2}$ concentrations, and a wide range of thermal and light conditions. It requires selecting the proper type of microalgae and then adapting to higher $\mathrm{CO}_{2}$ concentrations that could have the potential to produce useful byproducts, and function multi-purposely.

\section{REFERENCES}

[1] D. J. Stepan, R. E. Shockey, T. A. Moe and R. Dorn. "SUBTASK, 2.3-Carbon Dioxide Sequestering Using Microalgal Systems," U.S. Department of Energy, National Energy Technology Laboratory, 2001.

[2] B. Hileman, "U.S. Urged to Change $\mathrm{CO}_{2}$ Emissions Policy," Chemical Engineering News, Vol. 70, No. 1, 1992, pp. 16-22. doi:10.1021/cen-v070n008.p016

[3] O. Pulz and W. Gross, "Valuable Products from Biotechnology of Microalgae," Applied Microbiology and Biotechnology, Vol. 65, No. 3, 2004, pp. 635-648. doi:10.1007/s00253-004-1647-x

[4] Y. Chisti, "Biodiesel from Microalgae," Biotechnology Advances, Vol. 25, No. 3, 2007, pp. 294-306. doi:10.1016/j.biotechadv.2007.02.001

[5] E. Ono and J. L. Cuello, "Selection of Optimal Microal- 
gae Species for $\mathrm{CO}_{2}$ Sequestration," Proceedings 2nd Annual Conference on Carbon Sequestration, Alexandria, 2003, pp. 1-7.

[6] Oilgae, “Algae Oil Yield,” 2011. http://www.oilgae.com/algae/oil/yield/yield.html

[7] Biofpr, "The Promise and Challenges of Microalgal-Derived Biofuels," 2009.

http://www.afdc.energy.gov/afdc/pdfs/microalgal_biofuel s_darzins.pdf

[8] J. H. Fike, D. J. Parrish, J. Alwang and J. S. Cundiff, "Challenges for Deploying Dedicated, Large-Scale, Bioenergy Systems in the USA," Perspectives in Agriculture, Veterinary Science, Nutrition and Natural Resources, Vol. 2, No. 64, 2007, pp. 1-28.

[9] P. Chelf, L. M. Brown and C. E. Wyman, "Aquatic Biomass Resources and Carbon Dioxide," Biomass and Eioenergy, Vol. 4, No. 3, 1993, pp. 175-183. doi:10.1016/0961-9534(93)90057-B

[10] K. L. Kada, "Microalgae Production from Power Plant Flue Gas: Environmental Implications on a Life Cycle Basis," National Renewable Energy Laboratory publications, NREL/TP-510-29417, Golden, CO, 2001. doi:10.2172/783405

[11] J. R. Beneman, D. M. Tillet and J. C. Weissman, "Microalgae Biotechnology," Trends in Biotechnology, Vol. 5, No. 2, 1987, pp.47-53.

[12] E. S. Kikkinides, R. T. Yang and S. H. Cho, "Concentration and recovery of carbon dioxide from flue gas by pressure swing adsorption," Industrial Engineering Chemistry Research, Vol. 32, No. 11, 1993, pp. 2714-2720. doi:10.1021/ie00023a038

[13] D. Kilowatts, "America's Most Polluting Power Plants," Environmental, Integrity Project, National Renewable Energy Laboratory Publications, Washington DC, July 2007.

[14] J. Seckbach, H. Gross and M. B. Nathan, "Growth and Photosynthesis of Cyanidium Caldarium Cultured under Pure $\mathrm{CO}_{2}$," Israel Journal of Botany, Vol. 20, 1971, pp. 84-90,

[15] N. Hanagata, T. Takeuchi and Y. Fukuju, "Tolerance of Microalgae to High $\mathrm{CO}_{2}$ and High Temperature," Phytochemistry, Vol. 31, No. 10, 1992, pp. 3345-3348. doi:10.1016/0031-9422(92)83682-O

[16] M. Kodama, H. Ikemoto and S. Miyachi, “A New Species of Highly $\mathrm{CO}_{2}$-Tolreant Fast-Growing Marine Microalga Suitable for High-Density Culture," Journal of Marine Biotechnology, Vol. 1, No. 1, 1993, pp. 21-25.

[17] S. Miyairi, " $\mathrm{CO}_{2}$ Assimilation in a Thermophilic Cyanobacterium," Energy Conversion and Management, Vol. 36, No. 6-9, 1995, pp. 763-766. doi:10.1016/0196-8904(95)00116-U

[18] Y. Nakano, K. Miyatake, H. Okuno, K. Hamazaki, S. Takenaka, N. Honami, M. Kiyota, I. Aiga and J. Kondo, "Growth of Photosynthetic Algae Euglena in High $\mathrm{CO}_{2}$ Conditions and Its Photosynthetic Characteristics," Acta Horticulturae, Vol. 440, No. 9, 1996, pp. 49-54.
[19] H. Nagase, K. Eguchi, K. Yoshihara, K. Hirata and K. Miyamoto, "Improvement of Microalgal NOx Removal in Bubble Column and Airlift Reactors," Journal of Fermentation and Bioengineering, Vol. 86, No. 4, 1998, pp. 421-423. doi:10.1016/S0922-338X(99)89018-7

[20] K. Yoshihara, H. Nagase, K. Eguchi, K. Hirata and K. Miyamoto, "Biological Elimination of Nitric Oxide and Carbon Dioxide from Flue Gas by Marine Microalga NOA-113 Cultivation in a Long Tubular Photobioreactor," Journal of Fermentation and Bioengineering, Vol. 82, No. 4, 1996, pp. 351-354. doi:10.1016/0922-338X(96)89149-5

[21] Y. Miura, W. Yamada, K. Hirata, K., Miyamoto and M. Kiyohara, "Stimulation of Hydrogen Production in Algal Cells Grown under High $\mathrm{CO}_{2}$ Concentration and Low Temperature," Applied Biochemistry and Biotechnology, Vol. 39-40, No. 1, 1993, pp. 753-761. doi:10.1007/BF02919033

[22] H. Matsumoto, N. Shioji, A. Hamasaki, Y. Ikuta, Y. Fukuda, M. Sato, N. Endo and T. Tsukamoto, "Carbon Dioxide Fixation by Microalgae Photosynthesis Using Actual Flue Gas Discharged from a Boiler," Applied Biochemistry and Biotechnology, Vol. 51-52, No. 1, 1995 , 681-692. doi:10.1007/BF02933469

[23] S. Hirata, M. Hayashitani, M. Taya and S. Tone, "Carbon Dioxide Fixation in Batch Culture of Chlorella sp. Using a Photobioreactior with a Sunlight-Collection Device," Journal of fermentation and bioengineering, Vol. 81, No. 5, 1996, pp. 470-472. doi:10.1016/0922-338X(96)85151-8

[24] S. Hirata, M. Taya and S. Tone, "Characterization of Chlorella Cell Cultures in Batch and Continuos Operations under a Photoautotrophic Condition," Journal of Chemical Engineering of Japan, Vol. 29, No. 6, 1996, pp. 953-959. doi:10.1252/jcej.29.953

[25] K. Maeda, M. Owada, N. Kimura, L. Omata, and I. Karube, " $\mathrm{CO}_{2}$ Fixation from the Flue Gas on Coalfired Thermal Power Plant by Microalgae," Energy conversion Management, Vol. 36, No. 6-9, 1995, pp. 717-720. doi:10.1016/0196-8904(95)00105-M

[26] L. E. Graham and L. W. Wilcox, “Algae,” Prentice-Hall, Inc., Upper Saddle River, 2000.

[27] L. M. Brown, "Uptake of Carbon Dioxide from Flue Gas by Microalgae," Energy Conversion and Management, Vol. 37, No. 6-8, 1996, pp. 1363-1367.

[28] T. M. Sobczuk, F. G. Camacho, F. C. Rubio, F. G. A. Fernandez and E. M. Grima, "Carbon Dioxide Uptake Efficiency by Outdoor Microalgal Cultures in Tubular Airlift Photobioreactors," Biotechnology and Bioengineering, Vol. 67, No. 4, 2000, pp. 465-475. doi:10.1002/(SICI)1097-0290(20000220)67:4<465::AIDBIT10>3.0.CO;2-9

[29] J. A. Oswald, "Large-Scale Algal Culture Systems (Engineering Aspects)," In: L. J. Borowitzka and M. A. Borowitzka, Eds., Microalgal biotechnology, Cambridge University Press, Cambridge, 1988, pp. 357-395. 
[30] P. Tapie and A. Bernard, "Microalgae Production Technical and Economic Evaluations," Biotechnology and Bioengineering, Vol. 32, No. 7, 1988, pp. 873-885. doi:10.1002/bit.260320705

[31] S. Rados, B. Vaclav and D. Frantisek D, " $\mathrm{CO}_{2}$ Balance in Industrial Cultivation of Algae," Archives of Hydrobiology, Vol. 46, No. 12, 1975, pp. 297-310.

[32] Y. K. Lee and H. K. Hing, "Supplying $\mathrm{CO}_{2}$ to Photosynthetic Algal Cultures by Diffusion through Gas-Permeable Membranes," Applied Microbiology and Biotechnology, Vol. 31, No. 3, 1989, pp.298-301. doi:10.1007/BF00258413

[33] J. Beardall, S. Beer and J. A. Raven, "Biodiversity of Marine Plants in an Era of Climate Change: Some Predictions Based on Physiological Performance," Botanica Marina, Vol. 41, No. 1-6, 1998, pp. 113-124.

[34] P. Schippers, M. Lürling and M. Scheffer, "Increase of Atmospheric $\mathrm{CO}_{2}$ Promotes Phytoplankton Productivity," Ecology Letters, Vol. 7, No. 6, 2004, pp. 446-451. doi:10.1111/j.1461-0248.2004.00597.x

[35] J. K. Ward and B. R. Strain, "Elevated $\mathrm{CO}_{2}$ Studies: Past, Present and Future," Tree Physiology, Vol. 19, 1999, pp. 211-220.

[36] S. Beer and E. Koch, "Photosynthesis of Marine Microalgae and Seagrasses in Globally Changing $\mathrm{CO}_{2}$ Environments," Marine Ecology Progress Series, Vol. 141, 1996, pp. 199-204. doi:10.3354/meps141199

[37] J. Flexas, M. Ribas-Carbó, A. Diaz-Espejo, J. Galmés and H. Medrano, "Mesophyll Conductance to $\mathrm{CO}_{2}$ : Current Knowledge and Future Prospects," Plant, Cell and Environment, Vol. 31, No. 5, 2008, pp. 602-621. doi:10.1111/j.1365-3040.2007.01757.x

[38] T. Andersen, F. O. Andersen and O. Pedersen, "Increased $\mathrm{CO}_{2}$ in the Water around Littorella Uniflora Raises the Sediment $\mathrm{O}_{2}$ Concentration," Aquatic Botany, Vol. 84, No. 4, 2006, pp. 294-300. doi:10.1016/j.aquabot.2005.11.006

[39] T. Andersen and F. O. Andersen, "Effects of $\mathrm{CO}_{2}$ Concentration on Growth of Filamentous Algae and Littorella Uniflora in a Danish Softwater Lake," Aquatic Botany, Vol. 84, No. 3, 2006, pp. 267-271. doi:10.1016/j.aquabot.2005.09.009

[40] J. E. Kubler, A. M. Johnston and J. A. Raven, "The Effects of Reduced and Elevated $\mathrm{CO}_{2}$ and $\mathrm{O}_{2}$ on the Seaweed Lomentaria Articulate," Plant, Cell and Environment, Vol. 22, No. 10, 1999, pp. 1303-1310. doi:10.1046/j.1365-3040.1999.00492.x

[41] B. Tisserat, "Influence of Ultra-High Carbon Dioxide Concentrations on Growth and Morphogenesis of Lamiaceae Species in Soil," Journal of Herbs, Spices \& Medicinal Plants, Vol. 9, No. 1, 2002, pp. 81-89. doi:10.1300/J044v09n01_09

[42] Y-S. Yun and J. Moon Park, "Development of Gas Recycling Photobioreactor System for Microalgal Carbon Dioxide Fixation," Journal Korean Journal of Chemical Engineering, Vol. 14, No. 4, 1997, pp. 297-300. doi:10.1007/BF02706827
[43] L. Yue and W. Chen, "Isolation and Determination of Cultural Characteristics of a New Highly $\mathrm{CO}_{2}$ Tolerant Fresh Water Microalgae," Energy Conversion and Management, Vol. 46, No. 11-12, 2005, pp. 1868-1876. doi:10.1016/j.enconman.2004.10.010

[44] Y. Watanabe, N. Ohmura and H. Saiki, "Isolation and Determination of Cultural Characteristics of Microalgae Which Functions under $\mathrm{CO}_{2}$ Enriched Atmosphere," Energy Conversion and Management, Vol. 33, No. 5-8, 1992, pp. 545-552. doi:10.1016/0196-8904(92)90054-Z

[45] Y. Nakano, K. Hamasaki, S. Takenaka, K. Miyatake, A. Tani and I. Aiga, "Adaptation and the Mechanism of Euglena gracilis to High $\mathrm{CO}_{2}$ Conditions," CELSS Journal, Vol. 8, No. 2, 1995, pp. 7-12.

[46] Y. Yang and K. Gao, "Effects of $\mathrm{CO}_{2}$ Concentrations on the Freshwater Microalgae, Chlamydomonas Reinhardtii, Chlorella Pyrenoidosa and Scenedesmus Obliquus (Chlorophyta)," Journal of Applied Phycology, Vol. 15 , No. 5, 2003 , pp. 379-389. doi:10.1023/A:1026021021774

[47] A. Papazia, P. Makridisb, P. Divanachb and K. Kotzabasisa, "Bioenergetic Changes in the Microalgal Photosynthetic Apparatus by Extremely High $\mathrm{CO}_{2}$ Concentrations Induce an Intense Biomass Production," Physiologia Plantarum, Vol. 132, No. 3, 2008, pp. 338-349. doi:10.1111/j.1399-3054.2007.01015.x

[48] T. Shiraiwa, "Mechanism for the Acclimation of Photosynthetic Machinery to Change in Environmental $\mathrm{CO}_{2}$ Concentration in Eukaryotic Microalgae," 2005.

http://www.biol.tsukuba.ac.jp/ ikawa/shiraiwaHP/hp04/h ome04E.html

[49] D. O. Hessen, "Excess Carbon in Aquatic Organisms and Ecosystems: Physiological, Ecological, and Evolutionary Implications," Limnology and Oceanography, Vol. 53, No. 3, 2008, pp. 1685-1696. doi:10.4319/10.2008.53.4.1685

[50] M. Tsuzuki, M. Gantar, K. Aizawa and S. Miyachi, "U1trastructure of Dunaliella Tertiolecta Cells Grown under Low and High $\mathrm{CO}_{2}$ Concentrations," Plant Cell Physiology, Vol. 27, No. 4, 1986, pp. 737-739.

[51] E. W. Becker, "Microalgae: Biotechnology and Microbiology," Cambridge University Press, Cambridge, 1995.

[52] H. E. Glover and I. Morris, "Photosynthetic Characteristics of Coccoid Marine Cyanobacteria," Archives of Microbiology, Vol. 129, No. 1, 1981, pp. 42-46. doi:10.1007/BF00417177

[53] D. H. Pope, "Effects of Light Intensity, Oxygen Concentration, and Carbon Dioxide Concentration on Photosynthesis in Algae," Microbial Ecology, Vol. 2, No. 1, 1975, pp. 1-16. doi:10.1007/BF02010377

[54] Y. C. Jeon, C. W. Cho and Y. S. Yu, "Measurement of Microalgal Photosynthetic Activity Depending on Light Intensity and Quality," Biochemical Engineering Journal, Vol. 27, No. 2, 2005, pp. 127-131. doi:10.1016/j.bej.2005.08.017

[55] J. Kondo, "Growth of Photosynthetic Algae Euglena in High $\mathrm{CO}_{2}$ Conditions and Its Photosynthetic Characteris- 
tics," Acta Horticulturae, Vol. 440, No. 9, 1996, pp. 4954.

[56] H. T. Hsueh, H. Chu and S. T. Yu, "A Batch Study on the Bio-Fixation of Carbon Dioxide in the Absorbed Solution from a Chemical Wet Scrubber by Hot Spring and Marine Algae," Chemosphere, Vol. 66, No. 5, 2007, pp. 878-886. doi:10.1016/j.chemosphere.2006.06.022

[57] P. J. McGinn, K. E. Dickinson, S. Bhatti, J. Frigon, S. R. Guiot and S. J. B. O'Leary, "Integration of Microalgae Cultivation with Industrial Waste Remediation for Biofuel and Bioenergy Production: Opportunities and Limitations," Photosynthesis Research, 2011, (in Press). doi:10.1007/s11120-011-9638-0

[58] R. A. Andersen, "Algal Culturing Techniques," Elsevier Academic Press, Burlington, 2005.

[59] A. P. Carvalho, L. A. Meireles and F. Xavier, "Microalgal Reactors: A Review of Enclosed System Designs and
Performances," Biotechnology Progress, Vol. 22, No. 6, 2006, pp. 1490-1506. doi:10.1002/bp060065r

[60] D. A. Caron, J. C. Goldman and M. R. Dennet, "Effect of Temperature on Growth, Respiration, and Nutrient Regeneration by an Omnivorous Microflagellate," Applied and Environmental Microbiology, Vol. 52, No. 6, 1986, pp. 1340-1347.

[61] L. Brennan and P. Owend, "Biofuels from Microalgae-A Review of Technologies for Production, Processing, and Extractions of Biofuels and Co-Products," Renewable and Sustainable Energy Reviews, Vol. 14, No. 2, 2010, pp. 557-577. doi:10.1016/j.rser.2009.10.009

[62] A. Dauta, J. Devaux, F. Piquemal and L. Boumnich, "Growth Rate of Four Freshwater Algae in Relation to Light and Temperature," Hydrobiologia, Vol. 207, No. 1, 1990, pp. 221-226. doi:10.1007/BF00041459 